Supplement of Atmos. Chem. Phys., 15, 6455-6465, 2015

http://www.atmos-chem-phys.net/15/6455/2015/

doi:10.5194/acp-15-6455-2015-supplement

(C) Author(s) 2015. CC Attribution 3.0 License.

(c) (i)

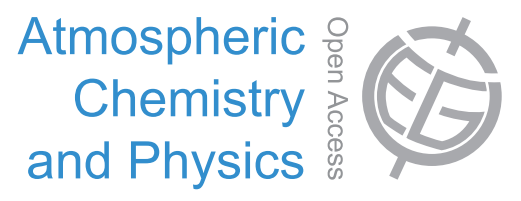

Supplement of

\title{
Survival and ice nucleation activity of bacteria as aerosols in a cloud sim- ulation chamber
}

\section{P. Amato et al.}

Correspondence to: P. Amato (pierre.amato@univ-bpclermont.fr)

The copyright of individual parts of the supplement might differ from the CC-BY 3.0 licence. 
1 Figure S1: Temporal evolution of the absolute (as opposed to normalized to the value

2 measured at $\mathrm{t}=30$ min after aerosolization) proportion of cultivable $P$. syringae $32 \mathrm{~b}-74$ and 3 P. fluorescens CGina-01 in each experiment. Details about the experimental conditions used 4 in each experiment are given in Table 1.

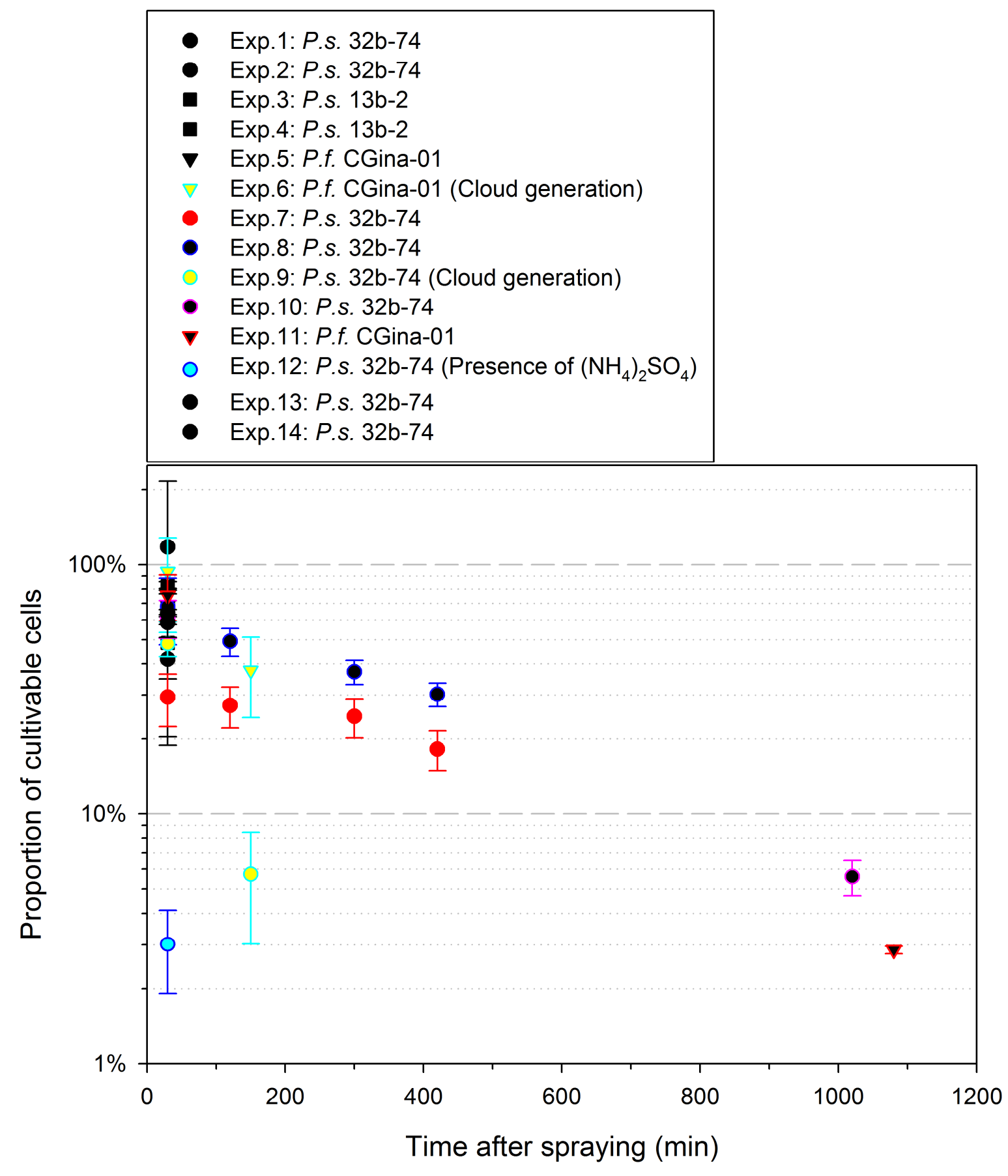

